Available online on 15.03.2021 at http://ujpr.org
Universal Journal of Pharmaceutical Research
An International Peer Reviewed Journal
Open access to Pharmaceutical research is an open access article distributed under the terms of the Creative Commons Attribution-Non
Commercial Share Alike 4.0 License which permits unrestricted non commercial use,
provided the original work is properly cited
Volume 6, Issue 1, 2021

\title{
CLINICAL FEATURES, AGE AND SEX DISTRIBUTIONS, RISK FACTORS AND THE TYPE OF BACTERIA ISOLATED IN PERIODONTITIS PATIENTS IN SANA'A, YEMEN \\ Khaled A AL-Haddad ${ }^{1}\left(\mathbb{D}\right.$, Mohammed Mohammed Ali Al-Najhi ${ }^{2}{ }^{\circledR}$, Al-Kasem Mohammed Abbas $^{3}{ }^{\mathbb{D}}$, Ameen Abdullah Yahya Al-Akwa ${ }^{1}{ }^{1}$, Hassan Abdulwahab Al-Shamahy ${ }^{4}{ }^{\mathbb{D}}$, Mohammed A Al-labani ${ }^{1}$ (it) \\ ${ }^{I}$ Orthodontics, Pedodontics and Prevention Department Faculty of Dentistry, Sana'a University, Yemen \\ ${ }^{2}$ Orthodontics, Pedodontics and Prevention Department Faculty of Dentistry, Genius University for Sciences and Technology, Dhamar city, Republic of Yemen. \\ ${ }^{3}$ Department of Maxillo-Facial, Faculty of Dentistry, Sana' a University, Republic of Yemen. \\ ${ }^{4}$ Departement of Basic Sciences, Faculty of Dentistry, Sana' a University, Republic of Yemen.
}

\section{ABSTRACT}

Background: Periodontitis is an inflammation caused by plaque in the surrounding dental structures. It is a major factor in adult tooth loss. There is lack of information on associated clinical features, risk factors and microbial etiology of periodontitis in Sana'a, Yemen.

Aim: The study focused on associated clinical features, risk factors and the separation and classification of bacteria in periodontitis and associated risk factors amongst patients attending dental clinics is Sana'a city.

Methods: First, 296 patients were admitted to the dental clinic at the Republican University Hospital and private dental clinics in Sana'a during a period of nearly one year, which began in December 2019 AD and ended in November 2020 AD, when they were diagnosed with dental diseases, then 49 of them were selected who are suffering from periodontitis, of whom 22 are males and 27 are females. Sterile paper points were used for the sample collection. Standard culture and biochemical techniques were used for the isolation and identification. Structured questionnaires were used to record clinical features, demographic variables and other risk factors of periodontitis.

Results: A total of 130 microorganisms were isolated from 49 patients with periodontitis. Male patients accounted for $14.4 \%$ and females $18.9 \%$ of the all 296 patients who attended the clinics. There was no important association between sex and periodontitis occurrence while there was significant association the younger age groups (45.4\% in<26 years of age). The most common signs and symptoms were swollen or puffy gums $(91.9 \%)$, bleed easily gums $(96 \%)$, halitosis $(96 \%)$, painful chewing $(87.8 \%)$, pus between teeth and gums (71.4\%), loose teeth or loss of teeth (44.9\%), gingival recession (83.7\%), spitting out blood when brushing or flossing teeth $(79.6 \%)$, and tender gums $(93.9 \%)$

Conclusion: This study is new in Sana'a city. The clinical features of preiodentitis in Yemen and the risk factors are similar to those reported in the literature elsewhere, but the isolated bacteria differ in frequency from those reported elsewhere, as some upper respiratory tract pathogens such as Streptococcus pyogenes are commonly isolated in this study. Knowledge of the clinical features, bacterial causes of gum disease, and risk factors is the key to successful periodontal therapy.

Keywords: bacteria agents, clinical features, periodontitis, risk factors, Sana'a, Yemen.

Article Info: Received 8 January 2020; Revised 5 February; Accepted 25 February, Available online 15 March 2021

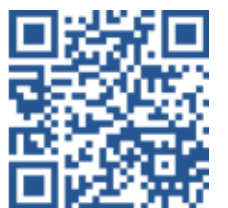

Cite this article-

AL-Haddad KA, Al-Najhi MMA, Abbas AKM, Al-Akwa AAY, Al-Shamahy HA, Al-labani MA. Clinical features, age and sex distributions, risk factors and the type of bacteria isolated in periodontitis patients in Sana'a, Yemen. Universal Journal of Pharmaceutical Research 2021; 6(1):1-8.

DOI: https://doi.org/10.22270/ujpr.v6il.532

Address for Correspondence

Prof. Hassan A. Al-Shamahy, Department of Basic Sciences, Faculty of Dentistry, Sana'a University, Republic of Yemen, Tel+967-770299847; E-mail: shmahe@yemen.net.ye

\section{INTRODUCTION}

There is a significant spread of periodontal disease worldwide, and identify the etiology is the solution to controlling it. Periodontal disease is characterized by a chronic bacterial infection with persistent inflamemation, breakdown of connective tissue and destruction of the alveolar bone ${ }^{1}$. Generally periodontal disease is classified into periodontitis and gingivitis. Gingivitis is inflammation of the gums initiated by the proliferation 
of dental plaque and is reversible. Gingivitis is possibly common in children up to 5 years old ${ }^{2}$. It is the result of inappropriate oral hygiene practices ${ }^{3}$. Periodontitis is a chronic inflammatory disease that begins with a buildup of dental biofilm plaque and continues through a disorganized immune response and is commonly started by gingivitis leading to irreversible demolition of the supportive tissues adjoining the tooth, together with the alveolar bone ${ }^{1,2,4}$. Periodontal disease is a multi-microbial, multifactorial disease, with numerous host factors involved in influential an individual's susceptibility to disease ${ }^{5}$. Several reports have been description that the onset and sequence of the disease is not only similar to the existence of pathogenic bacterial strains in the gums but also due to the absence or minimum levels of beneficial equivalents commensals in the susceptible host ${ }^{5-7}$. A limited number of periodontal pathogens have been reported in the complex biofilms to initiate periodontal disease. Data clarified that some bacterial strains in the gingival environment can cause gingivitis and bone destruction. These bacterial strains are known as periodontal pathogens ${ }^{8,9}$.

It is known that these periodontal disease pathogens possess, when present in even very small quantities, the capability to damage the gingival structure ${ }^{5}$. It is known that most periodontal pathogens are anaerobes, but biofilm can also accommodate facultative aerobes, capnophiles, and microaerophiles whose number depends on the environment in the developing biofilms and gingival pocket ${ }^{5}$. It became known that of $800-$ 1000 species that colonized the oral cavity, 50 species have been identified with strong links to periodontal disease ${ }^{10}$. These complexes were classified Socratic and Hafidian into 5 complexes, which are the yellow or early colonized complex, the green or secondary colonized complex, then the orange, purple and red complexes. The red compound is the secondary colony that is the major pathogens related with bleeding upon investigation $^{11}$. There is strong bacterial progression in oral cavity infection that may be predisposed by age, diet, or site of infection ${ }^{12}$. Nevertheless, in addition to periodontal disease pathogens, genetic and environmental factors predispose to disease progression. The risk of gum disease is determined by several factors including any health condition that leads to bacterial defense mechanisms defect such as diabetes, human immunodeficiency virus (HIV) and neutropenia. Tobacco smoking, Obesity, poor diet, and a inactive lifestyle are associated with an increased risk of periodontitis $^{13}$. In the early stages, periodontitis has few symptoms, and the disease has progressed significantly in many individuals before they seek treatment. Symptoms may include redness or bleeding of the gums while brushing the teeth, the use of dental floss or gnawing on solid food, frequent swelling of the gums, gingival recession gingival recession, halitosis, deep pockets between the teeth and the gums, loose teeth, and drifting of incisors $1,3,14$.

Periodontitis is the leading cause of tooth loss in adults universally and these people are at risk of edentulism, multiple tooth loss and masticatory impairment as a result of which a negative impact on nutrition, quality of life and self-esteem and thus a significant societal imposition - the economic impact and the cost of health care $^{3,14,15}$. Most of the information about the causes of periodontitis emerged from studies conducted in Europe and the United States of America, and some third world countries. Although there are some studies on oral and dental problems in Yemen ${ }^{16-25}$, no study has been conducted in Yemen on periodontitis ${ }^{26}$. So this study focused on associated clinical features, risk factors and the isolation and identification of bacteria in periodontitis and associated risk factors among patients attending some dental clinics is Sana'a city.

\section{SUBJECTS AND METHODS}

\section{Patients}

This study included 49 patients suffering from periodontitis, who were admitted to the dental clinic at the Republican University Hospital and private dental clinics (Al-Mortadda dental clinics, Al-Abany dental clinics and Al-Kahara dental clinics) in Sana'a, during a period of about one year, which started in December 2019 and ended in November 2020, of whom 22 were males and 27 were females.

\section{Data collection and microbial processing}

A questionnaire was filled out for each patient with the patient's personal, clinical data and risk factors. This included age, gender, occupation and relevant clinical information regarding bacterial oral infections. Also risk factors of contracting periodontitis. Cultures were obtained from the collected pocket by probes in order to isolate the various bacterial causative agents. First, the supragingival plaque was removed (without disturbing the subgingival plaque) and a bacterial sample was collected from the deepest periodontal pockets with a sterile probe. The samples were then placed in a vial containing $2 \mathrm{ml}$ of liquid thioglycolate enriched medium, sealed immediately and transported to the laboratory within 30 minutes. Bacteriological procedures were performed within one hour of sample collection. For germ cultures, the following media and conditions were used: Tryptic Soy Agar (TSA) with blood $(5 \%)$ and MacConkey agar plates - incubated at $35^{\circ} \mathrm{C}$ under $5 \% \mathrm{CO}_{2}$ and examined at 24 and 48 hours; Brucella agar enriched with Vitamin $\mathrm{K} 1$ and $\mathrm{CDC}+$ amikacin blood agar - incubated at $35^{\circ} \mathrm{C}$ anaerobically in a Gaspak jar (Oxoid Ltd). Cultures were examined for the presence of bacteria at 48 and $96 \mathrm{~h}$. Plates showing bacterial growth were retained until final processing and organism identification by classical standard techniques including culture colonies morphology, microscopy staining methods, and biochemical tests ${ }^{13,27}$.

\section{Data analysis}

Clinical, personal, and risk factors data as well as sample culture results entered into the questionnaire were analyzed by Epi Info, Version 6. All subjects with pockets less than $2 \mathrm{~mm}$ were considered to have periodentitis. To correlate the clinical features and potential risk factors for periodentitis, the data were examined in the form of case-control studies. For people with periodentitis, people with other dental diseases have been matched. Differences in categorical 
variables were assessed using Fisher's exact tests as appropriate. Ninety-five percent confidence intervals for odds ratios were calculated according to the Cornfield limits and $95 \%$ confidence intervals were calculated for simple ratios by an exact binomial method. The significance of the difference in the ratio and the odds ratio was analyzed, and a chi-square $\left(\chi^{2}\right)$ greater than 3.84 and a probability value $(p)$ less than 0.05 were considered statistically significant.

\section{Ethical approval}

Ethical approval was obtained from the Medical Research and Ethics Committee of the Faculty of Medicine and Health Sciences at Sana'a University. All data, including patient identification were kept confidential.

Table 1: The age and sex distribution of patients suffering from periodontitis.

\begin{tabular}{lcccccc}
\hline Sex & \multicolumn{2}{c}{$\begin{array}{c}\text { Periodontitis } \\
\text { n=49 }\end{array}$} & OR & 95\% CI & $\chi^{2}$ & $p$ \\
\cline { 2 - 3 } & No. & \% & & & & \\
\hline Male n=153 & 22 & 14.4 & 0.7 & $0.3-1.3$ & 1.1 & 0.29 \\
Female & 27 & 18.9 & 1.3 & $0.7-2.5$ & 1.08 & 0.29 \\
$\mathrm{n}=143$ & & & & & & \\
\hline Age in years & & & & & & \\
\hline$<16 \mathrm{n}=36$ & 8 & 22.2 & 1.5 & $0.6-3.5$ & 0.9 & 0.32 \\
$16-25 \mathrm{n}=56$ & 13 & 23.2 & 1.7 & $0.8-3.5$ & 2.2 & 0.13 \\
26-35 n=64 & 10 & 15.6 & 0.91 & $0.4-1.9$ & 0.05 & 0.82 \\
$36-45 \mathrm{n}=50$ & 6 & 12 & 0.68 & $0.3-1.5$ & 0.9 & 0.34 \\
$>45 \mathrm{n}=90$ & 12 & 13.3 & 0.7 & $0.34-1.4$ & 0.9 & 0.32 \\
\cline { 1 - 3 } Total $\mathrm{n}=296$ & 49 & 16.6 & & & & \\
\hline
\end{tabular}

\section{RESULTS}

Male patients accounted for $14.4 \%$ of the total periodontitis patients, and the female percentage was $18.9 \%$ from the total dental patients attending to the clinics.Table 1 show the age and gender distribution of patients with periodontitis. There was no significant association between gender and periodontitis occurrence. When age was considered a dependent factor for periodontitis, the rate of periodontitis was highest in the younger age groups $(45.4 \%$ in $<26$ years of age), while the rate in> 45 years was $13.3 \%$. Table 2 shows the importance periodontitis signs and symptoms among dental patients in Sana'a, Yemen. When compared periodontitis with other oral diseases, swollen or puffy gums occurred in $91.9 \%$ of periodontitis patients and occurred more than 30.2 times $(\mathrm{CI}=10.4-87, \mathrm{p}<0.001)$ of other oral diseases. Bleed easily gums occurred in $96 \%$ of periodontitis patients and occurred more than 67 times $(\mathrm{CI}=15-284, p<0.001)$ of other oral diseases. Halitosis occurred in $96 \%$ of periodontitis patients and occurred more than 88 times $(\mathrm{CI}=20-374, p<0.001)$ of other oral diseases. Painful chewing occurred in $87.8 \%$ of periodontitis patients and occurred more than 13.4 times $(\mathrm{CI}=5.4-32, p<0.001)$ of other oral diseases. Pus between teeth and gums occurred in $71.4 \%$ of periodontitis patients and occurred more than 15.3 times $(\mathrm{CI}=7.6-32, p<0.001)$ of other oral diseases. Loose teeth or loss of teeth occurred in $44.9 \%$ of periodontitis patients and occurred more than 5.2 times (CI=2.6-10.3, $p<0.001)$ of other oral diseases. Other symptoms and signs occurred $83.7 \%$ for gingival recession, $79.6 \%$ for spitting out blood when brushing or flossing teeth, $93.9 \%$ for tender gums with significant occurrence for all these signs as compared with other oral diseases. Table 3 shows the risk factors associated with periodontitis among dental patients in Sana'a, Yemen.

Table 2: The significance of signs and symptoms of periodontitis among dental disease patients in Sana'a

\begin{tabular}{|c|c|c|c|c|c|c|}
\hline \multirow[t]{2}{*}{ Signs and symptoms } & \multicolumn{2}{|c|}{$\begin{array}{l}\text { Periodontit } \\
\text { is } n=49\end{array}$} & \multirow[t]{2}{*}{ OR } & \multirow[t]{2}{*}{$95 \% C I$} & \multirow[t]{2}{*}{$\chi^{2}$} & \multirow[t]{2}{*}{$p$} \\
\hline & No. & $\%$ & & & & \\
\hline Swollen or puffy gums $n=112$ & 45 & 91.9 & 30.2 & $10.4-87$ & 72 & $<0.001$ \\
\hline $\begin{array}{l}\text { Bright red, dusky red or purplish } \\
\text { gums } n=145\end{array}$ & 44 & 89.8 & 12.7 & $4.8-32$ & 39 & $<0.001$ \\
\hline Tender gums $n=195$ & 46 & 93.9 & 10 & $3.1-331$ & 20 & $<0.001$ \\
\hline Bleed easily gums $n=111$ & 47 & 96 & 67 & $15-284$ & 85 & $<0.001$ \\
\hline $\begin{array}{l}\text { Bleeding during toothbrush or } \\
\text { after brushing } n=143\end{array}$ & 41 & 83.7 & 7.2 & $3.2-16$ & 29 & $<0.001$ \\
\hline $\begin{array}{l}\text { Spitting out blood when brushing } \\
\text { or flossing teeth } n=89\end{array}$ & 39 & 79.6 & 15.3 & $7.1-32$ & 68 & $<0.001$ \\
\hline Halitosis $n=99$ & 47 & 96 & 88 & $20-374$ & 102 & $<0.001$ \\
\hline Pus between teeth and gums $n=69$ & 35 & 71.4 & 15.6 & $7.6-32$ & 76 & $<0.001$ \\
\hline Loose teeth or loss of teeth $n=55$ & 22 & 44.9 & 5.2 & $2.6-10.3$ & 26 & $<0.001$ \\
\hline Painful chewing $n=129$ & 43 & 87.8 & 13.4 & 5.4-32 & 46 & $<0.001$ \\
\hline Gingival recession $n=188$ & 41 & 83.7 & 3.4 & $1.5-7.7$ & 10.2 & $<0.001$ \\
\hline Total $n=296$ & 49 & 16.6 & & & & \\
\hline
\end{tabular}


Table 3: The associated risk factors of periodontitis among dental disease patients in Sana'a Yemen.

\begin{tabular}{|c|c|c|c|c|c|c|}
\hline \multirow[t]{2}{*}{ Risk factors } & \multicolumn{2}{|c|}{$\begin{array}{c}\text { Periodontitis } \\
n=49\end{array}$} & \multirow[t]{2}{*}{$O R$} & \multirow[t]{2}{*}{$95 \% C I$} & \multirow[t]{2}{*}{$\chi^{2}$} & \multirow[t]{2}{*}{$p$} \\
\hline & No. & $\%$ & & & & \\
\hline Low Education level $n=95$ & 26 & 27.3 & 2.9 & $1.5-5.4$ & 11.8 & $<0.001$ \\
\hline Repeated History of Gingivitis $n=95$ & 29 & 59.2 & 3.2 & $1.7-6.1$ & 14.4 & $<0.001$ \\
\hline Poor oral health habits $n=151$ & 16 & 32.6 & 0.4 & $0.21-0.77$ & 7.9 & 0.004 \\
\hline Smoking or chewing tobacco $n=45$ & 12 & 24.4 & 0.74 & $0.2-1.8$ & 0.39 & 0.52 \\
\hline Chewing Qat $n=91$ & 31 & 63.2 & 5.3 & $2.8-10.2$ & 29 & $<0.001$ \\
\hline$*$ Hormonal changes $n=45$ & 6 & 12.2 & 0.74 & $0.2-1.8$ & 0.39 & 0.52 \\
\hline$*$ Recreational drug use $\mathrm{n}=6$ & 1 & 2 & 1.01 & $0.11-8.8$ & 0.001 & 0.99 \\
\hline Obesity $n=57$ & 17 & 34.7 & 2.7 & $1.3-5.4$ & 8.9 & 0.002 \\
\hline $\begin{array}{l}\text { Inadequate nutrition, including } \\
\text { vitamin } C \text { deficiency } n=71\end{array}$ & 10 & 20.4 & 1.2 & $0.5-2.5$ & 0.23 & 0.6 \\
\hline $\begin{array}{l}* \text { Certain medications that cause dry } \\
\text { mouth or gum changes } n=12\end{array}$ & 8 & 16.3 & 11.8 & $3.4-41$ & 22 & $<0.001$ \\
\hline $\begin{array}{l}* \text { Conditions that cause decreased } \\
\text { immunity } n=9\end{array}$ & 4 & 8.2 & 4.3 & $1.1-16.6$ & 5.2 & 0.02 \\
\hline Certain diseases $n=34$ & 16 & 32.7 & 6.1 & $2.8-13.2$ & 25.8 & $<0.001$ \\
\hline Total $n=296$ & 49 & 16.6 & & & & \\
\hline
\end{tabular}

There was a significant correlation between a frequent history of gingivitis $(\mathrm{OR}=3.2, \mathrm{CI}=1.7-6.1, \mathrm{p}<0.001)$, qat chewing $(\mathrm{OR}=5.3, \mathrm{CI}=2.8-10.2, \mathrm{p}<0.001)$, obesity $(\mathrm{OR}=2.7, \mathrm{CI}=1.3-5.4, p=0.004)$, some drugs that cause dry mouth or gingival changes $(\mathrm{OR}=11.8, \mathrm{CI}=3.4-41$, $p<0.001)$, conditions that cause decreased immunity $(\mathrm{OR}=4.3, \mathrm{CI}=1.1-16.6, p=0.02)$, and some diseases, such as diabetes, rheumatoid arthritis, and Crohn's disease $(\mathrm{OR}=6.1, \mathrm{CI}=2.8-13.2, \mathrm{p}<0.001)$; and the occurrence of periodontitis. Table 4 shows the number and percentage of the cultivated microorganisms from the 49 patients suffering from periodentitis . Multiinfections occurred in $89.8 \%$ of the periodentitis patients and the most common bacteria isolated were Actinobacillus actinomycetemcomitans (79.6\%), followed by Streptococcus pyogens (73.5\%) and Staphylococcus aureus (53.1\%). While the Bacteriodes species (20.4\%), Streptococcus mutans (16.3\%) and Anaerobic lactobacillus (4\%) were less isolated from the periodentitis patients. albicans was isolated in 4 cases $(10.2 \%)$.

\section{DISCUSSION}

Periodontal disease is an increasing health problem in Yemen. Currently, no work has been done to determine the clinical features, etiological and risk factors for periodontitis in Sana'a City, but little works have been done, they dealt with the spread of oral and dental diseases; and some dental and oral disorders ${ }^{16-25}$. In the current study, there was no significant association between sex and the incidence of periodontitis, and many other researchers appear to favor the female preference ${ }^{28,29}$. Also, current work contrasts with that of Ababneh and others, who reported a predisposition to males but current result is similar to that reported by Susin and Albander, which reported an equal distribution $^{30,31}$.

Table 4: The number and percentage of the cultivated microorganisms from the 49 patients suffering from periodontitis.

\begin{tabular}{|c|c|c|c|c|c|c|}
\hline \multirow[t]{2}{*}{ Bacterial isolates } & \multicolumn{2}{|c|}{ Total $n=49$} & \multicolumn{2}{|c|}{ Male $n=22$} & \multicolumn{2}{|c|}{$\begin{array}{c}\text { Female } \\
\mathbf{n}=27\end{array}$} \\
\hline & No. & $\%$ & No. & $\%$ & No. & $\%$ \\
\hline Streptococcus pyogens & 36 & 73.5 & 17 & 77.3 & 19 & 70.3 \\
\hline Staphylococcus aureus & 26 & 53.1 & 14 & 63.6 & 12 & 44.4 \\
\hline Bacteroides species & 10 & 20.4 & 7 & 31.8 & 3 & 11.1 \\
\hline $\begin{array}{l}\text { Actinobacillus } \\
\text { actinomycetemcomitans }\end{array}$ & 39 & 79.6 & 19 & 86.4 & 20 & 74 \\
\hline Streptococcus mutans & 8 & 16.3 & 3 & 13.6 & 5 & 18.5 \\
\hline Anaerobic lactobacil & 2 & 4 & 2 & 9 & 0 & 0 \\
\hline Enterobacteriaceae & 4 & 8 & 2 & 9 & 2 & 7.4 \\
\hline Candida albicans & 4 & 8 & 2 & 9 & 2 & 7.4 \\
\hline $\begin{array}{l}\text { Multi-infections (more } \\
\text { than } 2 \text { isolates) }\end{array}$ & 44 & 89.8 & 20 & 90.9 & 24 & 88.9 \\
\hline $\begin{array}{l}\text { No growth of potential } \\
\text { pathogens }\end{array}$ & 5 & 10.2 & 2 & 9.1 & 3 & 11.1 \\
\hline Total significant growth & 130 & & & & & \\
\hline
\end{tabular}


Age was a dependent factor for periodontitis in the current study, with periodontitis rate being higher in the younger age groups $(45.4 \%$ in $<26$ years), while it was lower at> 45 years $(13.3 \%)$ (Table 1$)$. Several authors believe that age is not a determining factor but a lifetime accumulation of disease $\mathrm{e}^{30-32}$. For people over the age of 31 , the probability of developing gingivitis increased by 5.17 times, and the likelihood of developing periodontitis increased by 2.28 times $^{30-32}$. In the current study, when comparing the clinical features of periodontitis patients with other oral diseases, the clinical signs and symptoms in Table 2 such as swollen or puffy gums, bleed easily gums, halitosis, painful chewing, pus between teeth and gums, loose teeth or loss of teeth, gingival recession, spitting out blood when brushing or flossing teeth, and tender gums occur more frequently in periodontitis patients than in patients with other oral diseases. This finding is similar to that reported in the literature in which previous signs and symptoms appeared in periodontitis more than other dental diseases ${ }^{33-35}$. In the current study, bleeding gums occurred in $96 \%$ of periodontitis patients and occurred 67 times more $(\mathrm{CI}=15-284, p<0.001)$ than other oral diseases. In a previous study by Maduakor $e t$ al., ${ }^{36}$ patients with bleeding gums showed an odds increase of 38.41 times the incidence of gingivitis and 2.58 times the incidence of periodontitis compared to patients without bleeding gums. It has also been reported that bleeding gums is one of the early signs of developing gum disease. This confirms the effect of maintaining good oral health and hygiene associated with preventing inflammation ${ }^{37,38}$.

In the current study higher prevalence of periodontitis among subjects with low education $(27.3 \%)$ with a significant correlation between a low education level and periodontitis, in which subjects with low school education were 2.9 times more likely to have periodontitis than subjects with a higher level of education $(\mathrm{OR}=2.9$ times, $\mathrm{CI}=1.5-5.4, p<0.001)$ (Table $3)$. A high prevalence of periodontitis has been reported among low-education patients in Nigeria, Jordan and Thailand ${ }^{30,36,39}$. This confirmed that in the United States of America, people with a low school education were three times more likely to have periodontitis than people with a higher education level $^{40}$ and it has been reported in many studies that there is a correlation between gum disease and educational level. In the current study, patients with a previous history of recurrent gingivitis were approximately 3.8 times more likely to have periodontitis than those without a previous history of gingivitis $(\mathrm{OR}=3.2, \mathrm{CI}=1.7-6.1, p<0.001)$ ( Table 3$)$. A previous frequent positive history of gingivitis has been reported by several researchers as a risk factor for developing gingivitis ${ }^{30,36,39}$. In the current study, poor oral health habits were not risk factors for periodontitis (odds ratio $=0.4$ ). This finding differs from most of the reported studies in that poor oral health habits (oral hygiene) lead to a risk factor for gingivitis and periodontitis $^{36-38}$. This finding may be because in current study, patients were compared with other oral disorders and not with healthy individuals. Khat or qat (Catha edulis) is a flowering plant inhabitant to
Ethiopia. Khat contains the alkaline cathinone, which is a stimulant that causes excitement, loss of appetite and euphoria. Chewing khat has a history as a social habit going back thousands of years similar to the use of coca leaves in South America and betel nuts in Asia ${ }^{41}$. It is estimated that up to $90 \%$ of adult males chew qat three to four hours per day in Yemen. There was a significant association between Khat chewing and periodontitis $(\mathrm{OR}=5.3, \mathrm{CI}=2.8-10.2, p<0.001)$. These results are similar to previous studies in Yemen where Khat chewing is a risk factor for oral disease ${ }^{24}$, and better research on Khat chewing and its potential association with oral and dental disorders should be conducted on a large scale. Aside from the physiological causes of xerostomia, the iatrogenic effects of medications are the most common cause ${ }^{42}$. A drug recognized to cause dry mouth can be called xerogenic ${ }^{43}$. More than 400 drugs are associated with dry mouth. Although dry mouth caused by medications is usually reversible, the situations for which these medications are prescribed are often chronic ${ }^{44}$. The likelihood of developing a xerostomia increases compared to the total number of drugs taken, whether or not individual drugs are dehydrating ${ }^{45}$. The sensation of dehydration usually begins shortly after starting the offending drug or after increasing the dose $\mathrm{e}^{42}$. There was a significant association between the use of drugs that cause xerostomia or gingival changes and the development of periodontitis $(\mathrm{OR}=11.8, \mathrm{CI}=3.4-41$, $p<0.001)$. These results are similar to previous studies that reported several medications associated with dry mouth, which is a risk factor for periodontitis ${ }^{36}$.

There was a significant correlation between obesity and develop periodontitis, $(\mathrm{OR}=2.7, \quad \mathrm{CI}=1.3-5.4$, $p=0.004)$. This result is similar to previous studies in which obesity is predisposing factors for dental and gums disorders ${ }^{36}$. There was a significant association between conditions causing decreased immunity and the development of periodontitis $(\mathrm{OR}=4.3, \mathrm{CI}=1.1$ 16.6, $p=0.02)$; and some diseases such as diabetes, rheumatoid arthritis, and Crohn's disease $(\mathrm{OR}=6.1$, CI $=2.8-13.2, \quad p<0.001)$; with the occurrence of periodontitis. These disorders can be described in several different ways: by the component (s) of the affected immune system, whether the immune system is overactive or inactive, and whether the condition is congenital or acquired ${ }^{46}$. These conditions usually make people more susceptible to dental and other local or systemic infections ${ }^{46}$. The polymicrobial pattern that is a feature of periodontal disease was obvious in this study, $89.8 \%$ in periodontitis, and this is in agreement with the work of many other researchers ${ }^{12,47-49}$. The occurrence of polymicrobial infection has important inferences for management as it changes the clinical course of disease, influences the choice of antimicrobial therapy and the expected response to treatment especially when it comes to pathogens that commonly exhibit antimicrobial resistance such as $S$. aureus $^{50}$. Aggregatibacter actinomycetecomitans was the most prevalent facultative anaerobe in periodontitis, $79.6 \%$. Of all the microorganisms in biofilm, three are said to be important in the initiation and progression of periodontal disease: A. actinomycetecomitans is named 
key pathogens or "red complex" bacterium", ${ }^{2,51} A$. actinomycetecomitans in aggressive chronic periodontitis patients ${ }^{52}$. It is reported to be strongly associated with destructive periodontal lesions ${ }^{5}$. It possesses many virulence factors including protease, leukotoxin, endotoxin, collagenase, fibroblast inhibition factor inducing bone resorption ${ }^{5}$. Staphylococcus aureus was isolated from $53.1 \%$ of used periodontitis patients, as did several researchers ${ }^{52,53}$. These microbes are known to easily become resistant to antibiotics, and may reach climax with super-infection. The capability to form biofilm has enabled Staphylococcus aureus to survive in this environment also ${ }^{49,54}$. Streptococcus pyogenes was isolated from $73.5 \%$ and Streptococcus mutans in $16.3 \%$ of our patients, and this result is similar to that previously reported in which Streptococcus species was detected in large numbers by several researchers $^{12,52}$. Some streptococci are useful to the host as colonization of the pocket in large numbers can delay the periodontal disease process ${ }^{55}$.

In current study, Enterobacteriaceae was isolated in $8 \%$ of patients with periodontitis (Table 4). Enterobacteriaceae is unusual in patients with periodontitis $^{56}$. Several studies have linked enteric bacilli to periodontal disease ${ }^{52}$. According to Botero and colleagues, their role in periodontitis is not clear but is thought to indicate super-infection ${ }^{57}$. They are thought to be opportunists that thrive after periodontal treatment. The drug of choice for the treatment of periodontal disease includes tetracycline, doxycycline, amoxicillin, and metronidazole. The gut bacteria illustrate resistance to these drugs and may consequently persist after taking them. Further studies are needed to explain its presence in the plaque biofilm and explain its role in periodontal infection ${ }^{57}$. Candida albicans was isolated in current study in $8 \%$ of patients with periodontitis, and several researchers including Daniluk et al., have reported that Candida albicans could have a role in the ultrastructure of gingival microbial plaques and in their attachment to periodontal tissue $\mathrm{e}^{25,58,59}$.

\section{CONCLUSION}

This study is new in Sana'a city. The clinical features of periodontitis in Yemen and the risk factors are similar to those reported in the literature elsewhere, but the isolated bacteria differ in frequency from those reported elsewhere, as some upper respiratory tract pathogens such as Streptococcus pyogens are commonly isolated in this study. Knowledge of the clinical features, bacterial causes of gum disease, and risk factors is the key to successful periodontal therapy.

\section{AUTHOR'S CONTRIBUTION}

All authors participated in overseeing clinical and laboratory work, data analysis, and manuscript writing and review.

\section{ACKNOWLEDGEMENTS}

The authors extend their thanks and appreciation to Genius University of Science and Technology, Dhamar City, Republic of Yemen, which supported this work, in particular Dr. Mohammed Mohammed Ali Al-Najhi, the generous scholar who usually supports medical education and research in Yemen.

\section{CONFLICT OF INTEREST}

No conflict of interest associated with this work.

\section{REFERENCES}

1. Yamamoto M, Kobayashi R, Kono T, Bolerjack B, Gilbert R. Induction of IL-10-producing CD4 T-cells in chronic Periodontitis. J Dental Res 2011;90(5):653-658. https://doi.org/10.1177/0022034510397838

2. Segura EP, Mendez L,Marquez E, Vargas A, Gregorio K, Martinez JL, Ilyna A. Effect of Carya Illinoinensis, Quercus rubra and Smilax glyciphylla extracts, pectin and papain on the dental biofilm microorganisms. J Pharm Pharmacog Res 2015; 3(5): 118-129. https://doi.org/10.5580/IJMB.54104

3. Tonetti MS, Jepsen S, Jin L, Otomo-Corgel J. Impact of the global burden of periodontal diseases on health, nutrition and wellbeing of mankind: A call for global action. J Clin Periodont 2017; 44:456-462. https://doi.org/10.1111/jcpe.12732

4. Suvan J, D'Aiuto F, Moles DR, Petrie A, Donos N. Association between overweight/obesity and periodontitis in adults. A systematic review. Obesity Rev 2011; 12(5):e381-404. https://doi.org/10.1111/j.1467-789X.2010.00808.x

5. Popova C, Dosseva-Panova V, Panov V. Microbiology of Periodontal diseases- A review. Biotech Biotechnol Equip 2013; 27(3), 3754-3759. https://doi.org/10.5504/BBEQ.2013.0027

6. Haffajee AD, Socransky SS. Periodontal Microbial Ecology 2005: Periodontol 2000. 2005; 38, 9-12.

7. Newman MG, Takei H, Klokkevold PR, Carranza FA. Carrianza`s clinical Periodontology $10^{\text {th }}$ ed, Middle East and African Edition: 2006.

8. Paster BJ, Olsen I, Aas JA, Dewhirst FE. The breadth of bacteria diversity in the human periodontal pocket and other oral sites. Periodontol 2006; 42: $80-87$. https://doi.org/10.1111/j.1600-0757.2006.00174.x

9. Socransky SS, Haffajee AD. In: Clinical Periodontology and Implant Dentistry, $4^{\text {th }}$ Ed. (J. Lindhe. T. Karring, N. Lang, Eds.) 2003: 106-149.

10. Colombo AP, Boches SK, Cotton SL, et al. Comparisons of subgingival microbial profiles of refractory periodontitis, severe periodontitis, and periodontal health using the humanoral microbe identification microarray. J Periodontol 2009; 80:1421-1432. https://doi.org/10.1902/jop.2009.090185

11. Socransky SS, Haffajee AD. Dental biofilms: difficult therapeutic targets. Periodontolol 2002, 28; 12-55.

12. Egwari LO, Obisesan B, Nwokoye NN. Micrrobiological status of periodontal diseases in Lagos, Nigeria. West Indian Med J 2009: 58 (4): 392-397. PMID: 20099785

13. Chapple IL, Bouchard P, Cagetti MG, et al. Interaction of lifestyle, behaviour or systemic diseases with dental caries and periodontal diseases: consensus report of group 2 of the joint EFP/ORCA workshop on the boundaries between caries and periodontal disease. J Clin Periodontol 2017; 44(Suppl 18), S39-S51. https://doi.org/10.1111/jcpe.12685 
14. Chapel IL, Van der Weijden F, Doerfer C, et al. Primary Prevention of Periodontitis: Managinging gingivitis. J Clin Periodontol 2015; 45(Suppl 16), S71-S76. https://doi.org/10.1111/jcpe.12366

15. Peterson PE, Ogawa HM. The global burden of periodontal disease: Towards integration with chronic disease prevention and control. Periodontol 2000, 2012;60, 15-39. https://doi.org/10.1111/j.1600-0757.2011.00425.x

16. Al-Sharani AA, Al-Hajj W, Al-Shamahy HA, Jaadan BM. The effect of nanosilver and chlorhexidine mouthwash on anaerobic periodontal pathogens counts. Universal J Pharm Res 2019; 4(5): 1-6. https://doi.org/10.22270/ujpr.v4i5.309

17. Alhasani AH, Ishag RA, Yahya Al-Akwa AY, Al Shamahy HA, Al-labani MA. Association between the Streptococcus mutans biofilm formation and dental caries experience and antibiotics resistance in adult females. Universal J Pharm Res 2020; 5(6):18-23. https://doi.org/10.22270/ujpr.v5i6.507

18. Abbas AM, Al-Kibsi TAM, Al-Akwa AAY, AL-Haddad KA, Al-Shamahy HA, Al-labani MA. Characterization and antibiotic sensitivity of bacteria in orofacial abscesses of odontogenic origin. Universal J Pharm Res 2020; 5(6):36-42. https://doi.org/10.22270/ujpr.v5i6.510

19. Al- deen AAS, Al-deen HMS, Abbas AKM, Al-Akwa AAY, AL-Haddad KA, Al-Shamahy HAW, Al-Sharani HM, Al-labani MA. Knowledge and perception of molar incisor hypomineralization among dental practitioners in Sana'a city - Yemen. Universal J Pharm Res 2020; 5(5):411. https://doi.org/10.22270/ujpr.v5i5.479

20. AL-Awadi TAM, AL-Haddad KA, Al-labani MA, AlShamahy HA. Prevalence of malocclusion among Yemeni children of primary schools. Universal J Pharm Res 2019; 5(1): 1-6. https://doi.org/10.22270 /ujpr.v5i1.329

21. Ulrahman MAASA, Yahya A, Al-Shamahy HA, Abbas AKMA. Occurrence of retromolar canal among a sample of Yemeni adults obtained from cone-beam computed tomography. Int Res J Med Med Sci 2020; 8(2): 35-41.

22. Alhadi Y, Rassem AH, Al-Shamahy HA, Al-Ghaffari KM Causes for extraction of permanent teeth in general dental practices in Yemen. Universal J Pharm Res 2019; 4(2): 15. https://doi.org/10.22270/ujpr. v4i2.231

23. Mutaher NJA, AL-Haddad KA, Al-Akwa AAY, Al-labani MA, Al-Shamahy HA, Zabara AQMQ, Al- deen HMS. Prevalence and causes of traumatic dental injuries to anterior teeth among primary school children in Sana'a city, Yemen. Universal J Pharm Res 2020; 5(3):38-43. https://doi.org/10.22270/ujpr.v5i3.329

24. Al-Kebsi AM, Arwa M Othman, Al-Kasem M A Abbas, Ebtihal M Madar, Hassan A. Al-Shamahy, Khaled M AlGaffari, Samera M. Naser Daname, Fuad L. Motareb. Oral c. albicans colonization and non-candida albicans candida colonization among university students, Yemen. Universal J Pharm Res. 2017; 2(5): 5-10. http://doi.org/10.22270/ujpr.v2i5.R2

25. Al-Haddad KA, Al-dossary OAE, Al-Shamahy HA. Prevalence and associated factors of oral non-Candida albicans Candida carriage in denture wearers in Sana'a city-Yemen. Universal J Pharml Res 2018; 3(4): 7-11. https://doi.org/10.22270/ujpr.v3i4.176

26. Joshi VM, Vandana KL. The detection of eight putative periodontal pathogens in adult and rapidly progressive periodontitis patients: An institutional study. Indian J Dental Res 2007; 18: 6-10. https://doi.org/10.4103/0970-9290.30914

27. Cheesbrough M. District laboratory practice in tropical countries. Cambridge: Cambridge University Press; 2010 https://doi.org/10.1017/CBO9780511581304

28. Page RC, Altman LC, Ebersole JL, Vandesteen GE, Dahlberg WH, Williams BL, Bowen T. Rapidly progressive periodontitis. A distinct clinical condition, 1983: J Periodontol 1983;54: 197-209. https://doi.org/10.1902/jop.1983.54.4.197
29. Albandar JM. Periodontal disease in North America. Periodontol 2000 2002a 29: 31-69. https://doi.org/10.1034/j.1600-0757.2002.290103.x

30. Ababneh KT, Hwaij Z.M., Khaders YS. Prevalence and risk indicators of gingivitis and periodontitis in a multicentre study in North Jordan: a Cross sectional study. Biomedcentral Oral Health 2012; 12:1. http://www.biomedcentral.com/1472-6831/12/1

31. Susin C, Albandar JM. Aggressive periodontitis in an urban population in Southern. Brazil J Periodontol 2005; 76: 468-475. https://doi.org/10.1902/jop.2005.76.3.468

32. Genco RJ. Current view of risk factors for periodontal diseases. J Periodontol 1996; 67;1041-1049. https://doi.org/10.1902/jop.1996.67.10.1041

33. Cisar JO, Kolenbrander PE, Mclntire FC. Specificity of coagreggation reactions between human oral streptococci and strains of Actinomyces viscosus or Actinomyces naeslundii, Infection and Immunity 1989; 24(3); 742-752. https://doi.org/10.1128/IAI.24.3.742-752.1979

34. Johnson, JL, Moore LV, Kaneko B, Moore WE. Actinomyces georgiae sp. Nov., Actinomyces gerencseriae sp. Nov., designation of two genos pecies of Actionomyces naeslundii and inclusion of $A$. naeslundii serotypes 11 and 111 and Actiomyces viscosus serotype 11 in A. naeslundii genospecies 2. Int J Syst Bacteriol 1990; 40(3): 273-286.

35. Kumar PS, Griffen AL, Moeschberger ML, Leys, EJ. Identification of candidate periodontal pathogens and beneficial species by quantitative $16 \mathrm{~S}$ clonal analysis. J Clinl Microbiol 2005; 43(8): 3944-3955. https://doi.org/10.1128/JCM.43.8.3944-3955.2005

36. Maduakor UC, Onyemelukwe NF, Maduakor SN, Azubuike NC, Onyemelukwe AO, Nnedu EB. Bacterial etiology and risk factors of periodontal diseases in enugu metropolis, South East Nigeria. The Int J Microbiol 2019; 16(1). https://doi.org/10.5580/IJMB.54104

37. Khader YS, Rice JC, Lefante JJ. Factors associated with periodontal diseases in a dental teaching clinic population in northern Jordan. J Periodontol 2003; 74:1610-1617. https://doi.org/10.1902/jop.2003.74.11.1610

38. Axelsson P, Nystrom B, Lindhe $\mathrm{J}$ The long term effect of plaque control program on tooth mortality, caries and periodontal disease in adults. Results after 30 years of maintenance. J Clin Periodontol 2004; 31:749-757. https://doi.org/10.1111/j.1600-051X.2004.00563.x

39. Torrungruang K, Tamsailom S, Rojanasomsith $\mathrm{K}$, et al. Risk indicators of periodontal disease in older Thai adults. J Periodontol 2005; 76:558-565. https://doi.org/10.1902/jop.2005.76.4.558

40. Borrel LN, Butt BA, Warren RC, Neighbors HW. The role of individual and neighborhood social factors on periodontitis: the third National Health and Nutrition Examination Survey. J Periodontol 2006; 77:444-453.

41. Al-Mugahed, Leen. Khat Chewing in Yemen: turning over a new leaf: khat chewing is on the rise in yemen, raising concerns about the health and social consequences. Bullet World Health Org 2008; 86 (10): 741-42. https://doi.org/10.2471/BLT.08.011008

42. Scully, Crispian. Oral and maxillofacial medicine: the basis of diagnosis and treatment $\left(2^{\text {nd }}\right.$ ed). Edinburgh: Churchill Livingstone 2008; 79-85. ISBN 978044306818

43. Tyldesley, Anne Field, Lesley Longman in collaboration with William R. Tyldesley's Oral medicine $\left(5^{\text {th }}\right.$ ed.). Oxford: Oxford University Press 2003; 90-93. ISBN 9780192631473.

44. Furness, S; Worthington, HV; Bryan, G; Birchenough, S; McMillan, R. Furness, Susan (ed.). Interventions for the management of dry mouth: topical therapies. Cochrane Data System Rev 2011; (12): CD008934. https://doi.org/10.1002/14651858.CD008934.pub2

45. Bouquot, Brad W. Neville, Douglas D. Damm, Carl M. Allen, Jerry E. Oral \& maxillofacial pathology $\left(2^{\text {nd }}\right.$. ed. $)$. Philadelphia: W.B. Saunders 2002; 398-399. ISBN 9780721690032 . 
46. Geha RS, Notarangelo LD, Casanova JL, et al. Primary immunodeficiency diseases: an update from the International Union of Immunological Societies Primary Immunodeficiency Diseases Classification Committee. J Allergy Clin Immun 2007; 120 (4): 776-94 https://doi.org/10.1016/j.jaci.2007.08.053

47. Saini S, Aparna N. Gupta N, Mahajan A. Microbial flora in Orodental infections. Indian J Med Microbiol 2003; 21 (2) 111-114. PMID: 17642993

48. Mane AK, Karmarkar AP, Bharadwaj RS. Anaerobic bacteria in subjects with chronic periodontitis and in periodontal health. J Oral Health Comm Dent 2009; 3(3):49-51. https://doi.org/10.5005/johcd-3-3-49

49. Salari MH, Kadkhoda, Z. Rate of cultivable sub-gingival periodontopathogenic bacteria in chronic periodontitis. J Oral Sci 2004; 46(3):157-161 https://doi.org/10.2334/josnusd.46.157

50. Peter BM, Jabra-Rizk MA, Graeme AO, Costerton JW, Shirtliff ME. Polymicrobial interactions: impact on pathogenesis and human disease. Clin Microbiol Rev 2012; 25(1): 193-213. https://doi.org/10.1128/CMR.00013-11

51. Sanz M, van Winkelhoff AJ, Herrera D, Dellemjinkippuw $\mathrm{N}$, Simon R, Winkel E. Differences in the composition of the subgingival microbiota of two periodontitis populations of different geographic locations. A comparison between Spain and the Netherlands. European J Dental Sci 2000; 108:383-92. https://doi.org/10.1034/j.1600-0722.2000.108005383.x

52. Amel Y, Bouziane D, Leila M, Ahmed, B. Microbiological study of periodontitis in the West of Algeria 2009: Advances in Medical and Dental Sciences. 2009 Sep 1:80-6.
53. Loberto J, Martins C, Santo S, Cortelli J, Jorge, A. Staphylococcus spp in the oral cavity and periodontal pockets. Brazilian J Microbiol 2004; 35:64-68 http://dx.doi.org/10.1590/S1517-83822004000100010

54. Cuesta AI, Jewtuchowicz G, Brusca ML, Rosa A.C. Prevalence of Staphylococcus spp and Candida spp in the oral cavity and periodontals pockets of periodontal disease patients. Acta Odontologica Latinoam 2010; 23(1):20-26. PMID: 20645638

55. Baehni PC, Guggenheim B. Potential of diagnostic microbiology for treatment and prognosis of dental caries and periodontal diseases. Critical Rev Oral Biol Med 1996; 7(3):259-277. https://doi.org/10.1177/10454411960070030401

56. Betancourth M, Arce R, Botero J, Jaramillo A, Cruz C, Contreras A. Unusual microorganisms in gingival sulcus and periodontal pockets 2006. Colombia Medica 2006; (37): 1-5.

57. Botero JE, Contreras A, Lafeaurie G, Jaramillo A, Betancourt M, Arce RM. Occurance of periodontopathic and super-infecting bacteria in chronic and aggressive periodontitis subjects in Colombian population. $\mathbf{J}$ Periodontol 2000; 78: 696-704.

https://doi.org/10.1902/jop.2007.060129

58. Daniluk T, Tokajuk G, Cylwik-Rokicka D, Rozkiewiez D, Zaremba ML, Stolowska W. Aerobic and anaerobic bacteria in subgingival and supragingival plaques of adult patients with periodontal disease. Adv Med Sci 2006; 51 Suppl 1:81-5. PMID: 17458065.

59. Jarvesivu A, Hietanen J, Rautemaa R, Sorsa T, Richardson M. Candida yeasts in chronic periodontitis tissues and subgingival microbial biofilms in vivo. Oral Diseases 2004; 10: 106-112.

https://doi.org/10.1046/j.1354-523x.2003.00978.x 